\title{
複ワイヤ駆動方式を用いた パラレル・メカニズムの運動自由度解析
}

\author{
永井 清*1 吉 田創*1 吉 森 大 悟*2
Kinematical Analysis of Parallel Mechanisms Using Multi-Wire Driven Method

Kiyoshi Nagai*1, Hajime Yoshida*1 and Daigo Yoshimori*2

\begin{abstract}
This paper discusses the kinematical analysis of parallel mechanisms using the multi-wire driven method. This method allows for the use of two or more wires attached to one actuator. One type of this method can produce passive constraints, whereas another type can produce active constraints in an area where a wire does not exist. The definition and the features of this method are then described. Then an analytical technique to obtain the number of degrees of freedom and possible directions of motion is proposed. Its validity is verified using an example.
\end{abstract}

Key Words: Multi-Wire Driven Method, Wire Mechanism, Parallel Mechanism, Kinematical Analysis

\section{1. はじめに}

ワイヤ駆動型パラレル・メカニズムは可動部が軽量化しやす い利点をもち, 高速メカニズム [1] やアシスト装置 $[2]$, ワイヤ 懸垂機構 [3] などに用いられてきた。川村らはワイヤ駆動型パ ラレル・メカニズムの可動部が全ての方向に能動的に動作でき る条件として Vector Closure [4] を示し, 可動部の可動範囲の 判定法を示した $[1]$. 大隈らは重力を利用したワイヤ懸垂系を含 むワイヤ駆動型パラレル・メカニズムの機構の操りの指標とし て, 可操作性棈円体を求めた [3]. これらの議論で登場するワイ ヤ駆動型パラレル・メカニズムは, 一つのアクチュエータが 1 本のワイヤの位置や力を制御する機構となっている.

本論文では, 一つのアクチュエータが複数のワイヤ先端の位 置や力を制御する機構について扱う。本論文ではこの機構を複 ワイヤ駆動方式と呼ぶことにする。また, 区別のため, 前述の 一つのアクチユエータが 1 本のワイヤ先端の位置や力を制御す る機構を単ワイヤ駆動方式と呼ぶことにする。この 2 種類のワ イヤ駆動方式で構成されるワイヤ駆動型パラレル・メカニズム を複ワイヤ・メカニズムと呼ぶことにし, 以下では, 可動部の 全方向に拘束が生じている複ワイヤ・メカニズムを対象として 議論を行う.

複ワイヤ・メカニズムを用いた場合, 後述するように, 可動

原稿受付 2010 年 12 月 22 日

$* 1$ 立命館大学

$* 2$ アイシン精機株式会社

${ }^{* 1}$ Ritsumeikan University

${ }^{* 2}$ Aisin Seiki Co., Ltd.

口本論文は学術性で評価されました。
部に接続された複数のワイヤの速度間に生じる拘束関係により, 可動部が特定の方向に動作できない受動拘束を生じさせること で拘束に必要なアクチュエータの数を減らすことが可能となる. また, アクチュエータの駆動力を分散させて可動部に伝えるこ となども可能となるという利点を持つ.

このような複ワイヤ・メカニズムの設計や制御を行うためには 可動部の運動方向および運動自由度の解析方法を正確に扱う必 要がある. しかし, 複ワイヤ・メカニズムに対して前述のVector Closure の条件を適用すると, 単ワイヤ駆動方式のみで構成さ れた機構とは異なり，条件を満たす機構であっても，必ずしも 可動部の全方向に能動拘束 [5] が生じるわけではなく, 受動拘 束 [5] が生じる方向もある. 能動拘束の方向は運動できる方向で あり, 受動拘束の方向は運動できない方向であるので, 複ワイ ヤ・メカニズムの設計においては，これらを区別する必要があ る.そこで本論文では, 可動部の拘束／非拘束の判定のために Vector Closure の条件を用いることとする，また，複ワイヤ． メカニズムを扱うための解析方法として, アクチュエー夕速度 と可動部の速度の間に成り立つ運動学を明らかにする定式化を 行い, それを用いて可動部の運動方向や運動自由度を解析する 方法を提案する.

以下 2 章で複ワイヤ駆動方式の定義および特徵を示した後, 3 章で複ワイヤ・メカニズムに対しての定式化を行い，4 章でそ れを用いて可動部の運動方向および運動自由度を定量的に解析 する方法を凸解析を用いて構築する。 凸解析は，ロボットハン ドの可操作性凸多面体を求める方法 [6] や, 不完全な接触をも つ把持の許容外力集合を求める方法 [7] などで用いられている 解析手法である。 また， 5 章では例題を用いることで，解析方 
法の妥当性を検証する.

\section{2. 複ワイヤ駆動方式の定義と特長と問題定義}

\section{1 複ワイヤ駆動方式の定義}

$n$ 次元空間を対象としたワイヤ駆動型パラレル・メカニズム の可動部を拘束するためには, $(n+1)$ 本以上のワイヤが必要で あり, 重力を 1 本のワイヤとみなせる場合には $n$ 本以上のワイ ヤが必要であることが知られている [1] [3]. また，川村らが示し た Vector Closure の条件 [4] は，ワイヤが弛まずに可動部を全 方向拘束するための条件とみなすことができる，そこで，議論 を簡単にするために本章で扱うワイヤ駆動型パラレル・メカニ ズムは Vector Closure の条件を満たす機構であることとする.

まず，一つのアクチュエータが制御するワイヤの本数や，可 動部に加えるワイヤ張力の数に着目し, 以下の二つの駆動方式 を定義する。

単ワイヤ駆動方式（Uni-wire Driven Method）:

一つのアクチュエータが可動部に接続された 1 本のワ イヤの長さ, 速度あるいは張力を決定する駆動方式.

複ワイヤ駆動方式（Multi-wire Driven Method）:

一つのアクチユエータが可動部に接続された複数のワ イヤの長さ, 速度あるいは張力を決定する駆動方式.

単ワイヤ駆動方式は, 文献 [1]〜 [3] などで一般的に利用され ている駆動方式である. それに対して, 複ワイヤ駆動方式は, 自 立支援用パワーアシスト装置 [8] で利用している駆動方式であ る. 複ワイヤ駆動方式は一つのアクチュエータにより, 同時に 複数のワイヤの速度あるいは張力を制御する。しかし, それら の速度／張力は独立ではなく, 速度間／張力間に拘束関係が発 生する. この拘束関倸の利用により, 複ワイヤ駆動方式は, 機 器を構成する際に，様々な特長を持たせることができる，以下 で本論文で扱う複ワイヤ駆動方式の二つの型を定義する.

速度拘束型（Velocity Constraint Type）:

一つのアクチュエータが複数のワイヤの速度を決定し,

複数のワイヤの速度間に拘束が生じる型.

力拘束型 (Force Constraint Type):

一つのアクチュエータが複数のワイヤの張力を決定し,

複数のワイヤの張力間に拘束が生じる型.

\section{2 複ワイヤ駆動方式の特徵}

次に, 例を用いて速度拘束型, 力拘束型について説明する. Fig. 1 (a) に速度拘束型の例をあげる．Fig. 1(a)のように，一 つのアクチュエータで可動部につながる 2 本のワイヤを巻き取 る機構の場合, アクチュエータの巻き取り速度とすべてのワイ ヤ速度は等しくなる。 よって平面運動を対象とした場合, 可動 部は回転方向に対して受動的な拘束が発生するという特徵を持 つ. なお， 2 本のワイヤの張力は, 可動部の重心など他の要因 によって別途定まる. 力拘束型の例を Fig. 1 (b) に示す. 議論 を簡単にするために本論文で扱うプーリの重さはないものとす る. 力拘束型では, プーリを用いて, 一つのアクチュエータの 駆動力を可動部に対し分散させて伝達することやワイヤを張っ ていない方向に力を発生させることができる，また，力拘束型

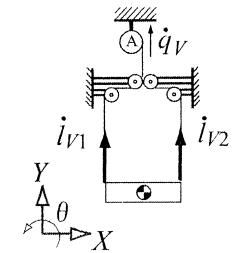

(a) Velocity constraint

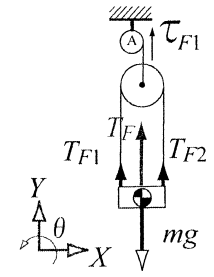

(b) Force constraint
Fig. 1 Two types of multi-wire driven system

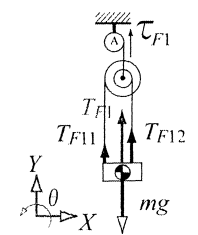

(a) Example1

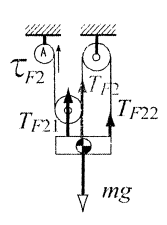

(b) Example2

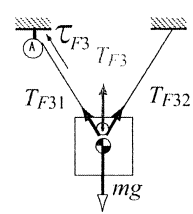

(c) Example3
Fig. 2 An example of force constraint type

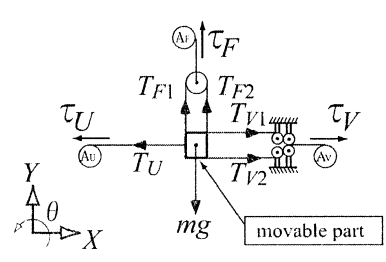

(a) Forces

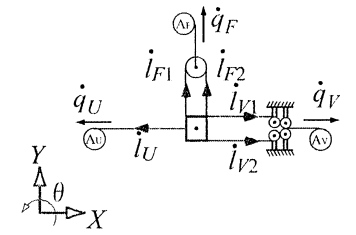

(b) Velocities
Fig. 3 An example of multi-wire driven parallel mechanism

の構成例を Fig. 2 に示す. Fig. 2 (a) は同一軸をもつプーリの 半径比を変えることで駆動力の分散の割合を決定する機構であ る. また, Fig. 2 (b) は複数のプーリを用いることで可動部に対 し駆動力の定数倍の力を加える機構であり, Fig. 2 (c) はワイヤ が張られていない方向へ力を発生する機構である。 な㧍, 各部 のワイヤの速度は, 可動部の重心など他の要因により定まる。

\section{3 複ワイヤ・メカニズムの問題定義}

複ワイヤ駆動方式を用いてパラレル・メカニズムを構成する 際, これらの機構を複ワイヤモジュールと呼ぶ構成要素として 用いることができる，本論文では，Fig. 3 にあるような平面 3 自由度の動作を対象として, 可動部に単ワイヤモジュール, 速 度拘束型複ワイヤモジュール, 力拘束型複ワイヤモジュールを それぞれ接続することで可動部に対して能動拘束や受動拘束が 生じるようなワイヤ・メカニズムを扱う対象とし，このワイヤ・ メカニズムの可動部の運動自由度や運動方向を解析する方法を 構築することを本論文の目的とする。

次章以降では, 複ワイヤ・メカニズムの定式化を行い, 可動 部の運動自由度と運動方向を求める方法について述べる.

\section{3. 複ワイヤ・メカニズムの運動学}

\section{1 複ワイヤ・メカニズムの運動学の導出}

前章で示したように, 重力依存型のパラレルワイヤ・メカニ ズムには，単ワイヤ駆動方式と複ワイヤ駆動方式がある。また， 複ワイヤ駆動方式には, 速度拘束型の特長を持つものと, 力拘 束型の特長を持つものがある。本章では，六次元空間を対象と した単ワイヤモジュール㧍よび速度拘束型と力拘束型の複ワイ 
ヤモジュールから構成される重力依存型パラレル・メカニズム の運動学と静力学を定式化する。まず, 各駆動方式ごとにアク チュエータとワイヤとの関係を表す運動学関係式，およびワイ ヤと可動部との関係を表す運動学関係式を定式化し, それらを まとめることで, アクチュエータと可動部の関係を表す運動学 関係式を定式化する。次に各駆動方式ごとに定式化した関係式 をまとめることで複ワイヤ・メカニズム全体の運動学および静 力学の関係式を定式化する.

まず，各駆動方式ごとの運動学および静力学の関係式は以下 で示すように定式化される. なお, 以下の議論における速度, 張 力, 駆動力はすべてベクトル量である.

3.2 単ワイヤモジュールと複ワイヤモジュール

3.2 .1 単ワイヤモジュール

単ワイヤモジュールにおけるアクチュエータとワイヤの関係 を示す運動学および静力学の関係式は次式のように表される.

$$
\begin{gathered}
\dot{\boldsymbol{q}}_{U}=\dot{\boldsymbol{l}}_{U} \\
\boldsymbol{T}_{U}=\boldsymbol{\tau}_{U}
\end{gathered}
$$

ただし， $\dot{\boldsymbol{q}}_{U}, \dot{\boldsymbol{l}}_{U}$ はそれぞれ単ワイヤモジュールのアクチュエータ 速度とワイヤ速度である. また, $\boldsymbol{T}_{U}\left(=\left[\begin{array}{ll}T_{U 1} & T_{U 2} \cdots T_{U \alpha_{U}}\end{array}\right]^{\mathrm{T}} \in\right.$ $\left.\mathcal{R}^{\alpha_{U}}\right)$ は可動部に加える張力, $\boldsymbol{\tau}_{U}\left(=\left[\begin{array}{lll}\tau_{U 1} & \tau_{U 2} \cdots \tau_{U \alpha_{U}}\end{array}\right]^{\mathrm{T}} \in\right.$ $\left.\mathcal{R}^{\alpha_{U}}\right)$ はアクチュエータの駆動力, $\alpha_{U}$ はアクチュエータの数 である。

また，単ワイヤモジュールのワイヤ張力 $\boldsymbol{T}_{U}$ が可動部の重心 に加える合力 $\boldsymbol{F}_{U}$ は次式により表される.

$$
\boldsymbol{F}_{U}=\boldsymbol{W}_{U} \boldsymbol{T}_{U}
$$

ただし， $\boldsymbol{F}_{U}=\left[\begin{array}{llllll}f_{U x} & f_{U y} & f_{U z} & n_{U x} & n_{U y} & n_{U z}\end{array}\right]^{\mathrm{T}} \in \mathcal{R}^{6}$,

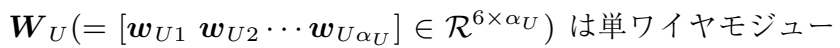
ルのワイヤ行列, $\boldsymbol{w}_{U i}=\left[\boldsymbol{e}_{U i} \boldsymbol{p}_{U i} \times \boldsymbol{e}_{U i}\right]^{\mathrm{T}} \in \mathcal{R}^{6}$ であり, $\boldsymbol{e}_{U i}$ は $i$ 番目ワイヤの基底ベクトル, $\boldsymbol{p}_{U i}$ は可動部の重心位置から $i$ 番目のワイヤ取り付け位置までのベクトルである.

ここで, 式（3）よりワイヤと可動部との間の運動学関係式は, 可動部の速度 $\boldsymbol{v}$ を用いて次式で表される。

$$
\dot{\boldsymbol{l}}_{U}=\boldsymbol{W}_{U}^{\mathrm{T}} \boldsymbol{v}
$$

また，式（1），(4）より，単ワイヤモジュールにおけるアクチュ エータと可動部との間の関係式を次式のように表すことができる.

$$
\dot{\boldsymbol{q}}_{U}=\boldsymbol{W}_{U}^{\mathrm{T}} \boldsymbol{v}
$$

\section{2 .2 速度拘束型複ワイヤモジュール}

2 章の Fig. 1 (a) のような速度拘束型複ワイヤ駆動方式にお ける運動学関係式は次式のように表される。

$$
\dot{\boldsymbol{l}}_{V}=\boldsymbol{J}_{V} \dot{\boldsymbol{q}}_{V}
$$

ただし， $\dot{\boldsymbol{l}}_{V}, \dot{\boldsymbol{q}}_{V}$ はそれぞれは速度拘束型複ワイヤモジュー ルのワイヤ速度とアクチュエー夕速度である。また， $\boldsymbol{J}_{V}(=$ $\left[\boldsymbol{J}_{V 1} \boldsymbol{J}_{V 2} \cdots \boldsymbol{J}_{V \alpha_{V}}\right] \in \mathcal{R}^{\left.K_{V} \times \alpha_{V}\right)}$ はアクチュエータ速度とワ イヤ速度を結びつけるヤコビ行列であり， $\alpha_{V}$ はアクチュエー
夕の数, $K_{V}$ はワイヤ総数である.

また, 式（6）より静力学関係式を導くと次式のようになる.

$$
\boldsymbol{\tau}_{V}=\boldsymbol{J}_{V}^{\mathrm{T}} \boldsymbol{T}_{V}
$$

ただし， $\boldsymbol{\tau}_{V}\left(=\left[\begin{array}{ll}\tau_{V 1} & \tau_{V 2} \cdots \tau_{V \alpha_{V}}\end{array}\right]^{\mathrm{T}} \in \mathcal{R}^{\alpha_{V}}\right)$ は速度拘 束型複ワイヤモジュールのアクチュエータの駆動力, $\boldsymbol{T}_{V}(=$ $\left.\left[\boldsymbol{T}_{V 1}^{\mathrm{T}} \boldsymbol{T}_{V 2}^{\mathrm{T}} \cdots T_{V \alpha_{V}}^{\mathrm{T}}\right]^{\mathrm{T}} \in \mathcal{R}^{K_{V}}\right)$ は可動部に加える張力である.

ここで例として, Fig.1(a)の場合, $\boldsymbol{i}_{V}=\left[i_{V 1}, i_{V 2}\right]^{T}, \boldsymbol{J}_{V}=$ $[1,1]^{T}$ とおくことで次式のように表すことができる.

$$
\left[\begin{array}{l}
i_{V 1} \\
i_{V 2}
\end{array}\right]=\left[\begin{array}{l}
1 \\
1
\end{array}\right] \dot{\boldsymbol{q}}_{V}
$$

この式はアクチュエータ速度と 2 本のワイヤの速度が常に等し いということを表している。

また, 速度拘束型複ワイヤモジュールのワイヤ張力 $\boldsymbol{T}_{V}$ が可動 部の重心に加える合力 $\boldsymbol{F}_{V}$ は, 速度拘束型複ワイヤモジュール のワイヤ行列 $\boldsymbol{W}_{V}\left(=\left[\boldsymbol{w}_{V 11} \boldsymbol{w}_{V 12} \cdots \boldsymbol{w}_{V \alpha_{V} k_{V \alpha_{V}}}\right] \in \mathcal{R}^{6 \times K_{V}}\right)$ を用いると次式で表される。

$$
\boldsymbol{F}_{V}=\boldsymbol{W}_{V} \boldsymbol{T}_{V}
$$

ただし, $\boldsymbol{F}_{V}=\left[f_{V x} f_{V y} f_{V z} n_{V x} n_{V y} n_{V z}\right]^{\mathrm{T}} \in \mathcal{R}^{6}, \boldsymbol{w}_{V i j}=$ $\left[\boldsymbol{e}_{V i j} \boldsymbol{p}_{V i j} \times \boldsymbol{e}_{V i j}\right]^{\mathrm{T}} \in \mathcal{R}^{6}$ であり, $\boldsymbol{e}_{V i j}$ は $i$ 番目のアクチュ エータの $j$ 番目ワイヤの基底ベクトル, $\boldsymbol{p}_{V i j}$ は可動部の重心 位置から $i$ 番目のアクチュエータの $j$ 番目ワイヤ取り付け位置 までのベクトルである. また, 式 (9) よりワイヤと可動部との 間の運動学関係式は次式のようになる。

$$
\dot{\boldsymbol{l}}_{V}=\boldsymbol{W}_{V}^{\mathrm{T}} \boldsymbol{v}
$$

ここで, 式 (6), （10）より，速度拘束型複ワイヤモジュール におけるアクチュエータと可動部との間の関係式を次式のよう に表すことができる

$$
\boldsymbol{J}_{V} \dot{\boldsymbol{q}}_{V}=\boldsymbol{W}_{V}^{\mathrm{T}} \boldsymbol{v}
$$

\subsection{3 力拘束型複ワイヤモジュール}

力拘束型複ワイヤモジュールの場合, アクチュエータの駆動 力とワイヤ張力の間に拘束関係があるので, まず, 静力学関係 式を求め, その後運動学を求めることにする.

力拘束型複ワイヤモジュールにおける静力学と運動学の関係 式は次式のようになる。

$$
\begin{gathered}
\boldsymbol{T}_{F}=\boldsymbol{J}_{F}^{\mathrm{T}} \boldsymbol{\tau}_{F} \\
\dot{\boldsymbol{q}}_{F}=\boldsymbol{J}_{F} \dot{\boldsymbol{l}}_{F}
\end{gathered}
$$

ただし, $\boldsymbol{T}_{F}\left(=\left[\boldsymbol{T}_{F 1}^{\mathrm{T}} \boldsymbol{T}_{F 2}^{\mathrm{T}} \cdots \boldsymbol{T}_{F K_{F}}^{\mathrm{T}}\right]^{\mathrm{T}} \in \mathcal{R}^{K_{F}}\right)$ は力拘束型複 ワイヤモジュールのワイヤ張力, $\boldsymbol{J}_{F}\left(=\left[\begin{array}{lll}\boldsymbol{J}_{F 1}^{\mathrm{T}} & \boldsymbol{J}_{F 1}^{\mathrm{T}} \cdots \boldsymbol{J}_{F \alpha_{F}}^{\mathrm{T}}\end{array}\right]^{\mathrm{T}} \in\right.$ $\mathcal{R}^{\left.\alpha_{F} \times K_{F}\right)}$ はアクチュエータ速度とワイヤ速度を結びつけるヤ コビ行列, $\boldsymbol{\tau}_{F}\left(=\left[\begin{array}{lll}\tau_{F 1} & \tau_{F 2} \cdots \tau_{F \alpha_{F}}\end{array}\right]^{\mathrm{T}} \in \mathcal{R}^{\alpha_{F}}\right)$ はアクチュエー 夕の駆動力であり， $\alpha_{F}$ は力拘束型複ワイヤ駆動方式のアクチュ エータの数, $K_{F}$ は力拘束型のワイヤ総数である. また, $\dot{\boldsymbol{q}}_{F}$, $i_{F}$ はそれぞれ力拘束型複ワイヤモジュールのアクチュエータ速 
度とワイヤ速度である．

ここで例として, Fig. 1(b) の場合, $\boldsymbol{T}_{F}=\left[T_{F 1}, T_{F 2}\right]^{\mathrm{T}}$, $\boldsymbol{J}_{F}^{\mathrm{T}}=[1 / 2,1 / 2]^{\mathrm{T}}$ とおくことで次式のように表すことができる.

$$
\left[\begin{array}{l}
T_{F 1} \\
T_{F 2}
\end{array}\right]=\left[\begin{array}{c}
\frac{1}{2} \\
\frac{1}{2}
\end{array}\right] \tau_{F}
$$

この式は 2 本のワイヤ張力の和がアクチュエータの駆動力と等 しいということを表している.

また, 力拘束型複ワイヤモジュールのワイヤ張力 $\boldsymbol{T}_{F}$ が可動 部の重心に加える合力 $\boldsymbol{F}_{F}$ は, 力拘束型複ワイヤモジュール

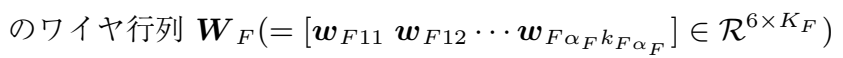
を用いると次式で表される。

$$
\boldsymbol{F}_{F}=\boldsymbol{W}_{F} \boldsymbol{T}_{F}
$$

ただし, $\boldsymbol{F}_{F}=\left[f_{F x} f_{F y} f_{F z} n_{F x} n_{F y} n_{F z}\right]^{\mathrm{T}} \in \mathcal{R}^{6}, \boldsymbol{w}_{F i j}=$ $\left[\begin{array}{l}\boldsymbol{e}_{F i j} \boldsymbol{p}_{F i j} \times \boldsymbol{e}_{F i j}\end{array}\right]^{\mathrm{T}} \in \mathcal{R}^{6}$ であり, $\boldsymbol{e}_{F i j}$ は $i$ 番目のアクチュ エータの $j$ 番目ワイヤの基底ベクトル, $\boldsymbol{p}_{F i j}$ は可動部の重心 位置から $i$ 番目のアクチュエータの $j$ 番目ワイヤ取り付け位置 までのべクトルである.

式（15）より運動学関係式は次式のようになる.

$$
\dot{\boldsymbol{i}}_{F}=\boldsymbol{W}_{F}^{\mathrm{T}} \boldsymbol{v}
$$

ここで, 式 (13), (16) より, 力拘束型複ワイヤモジュールに おけるアクチュエータと可動部との間の関係式を次式のように 表すことができる.

$$
\dot{\boldsymbol{q}}_{F}=\boldsymbol{J}_{F} \boldsymbol{W}_{F}^{\mathrm{T}} \boldsymbol{v}
$$

\section{3 機構全体の運動学}

次に, Fig. 4 のように重力の効果を含めて Vector Closure の条件を満たすメカニズムの定式化を行う. Fig. 4 の機構の場 合, 各ワイヤ駆動機構が可動部に対して並列結合で接続されて いるため, 式 (5), (11), （17）より次式に示すようなメカニ ズム全体のアクチュエータ速度と可動部の速度の関係式が成り 立つ.

$$
\widetilde{\boldsymbol{J}}_{V} \dot{\boldsymbol{q}}=\boldsymbol{W}_{M}^{\mathrm{T}} \boldsymbol{v}
$$

ただし，

$$
\begin{gathered}
\dot{\boldsymbol{q}}=\left[\dot{\boldsymbol{q}}_{U}^{\mathrm{T}} \dot{\boldsymbol{q}}_{V}^{\mathrm{T}} \dot{\boldsymbol{q}}_{F}^{\mathrm{T}}\right]^{\mathrm{T}} \\
\widetilde{\boldsymbol{J}}_{V}=\left[\begin{array}{ccc}
\boldsymbol{E}_{U} & \mathbf{0} & \mathbf{0} \\
\mathbf{0} & \boldsymbol{J}_{V} & \mathbf{0} \\
\mathbf{0} & \mathbf{0} & \boldsymbol{E}_{F}
\end{array}\right] \\
\boldsymbol{W}_{\boldsymbol{M}}=\left[\begin{array}{lll}
\boldsymbol{W}_{U} & \boldsymbol{W}_{V} & \boldsymbol{W}_{F} \boldsymbol{J}_{F}^{\mathrm{T}}
\end{array}\right]
\end{gathered}
$$

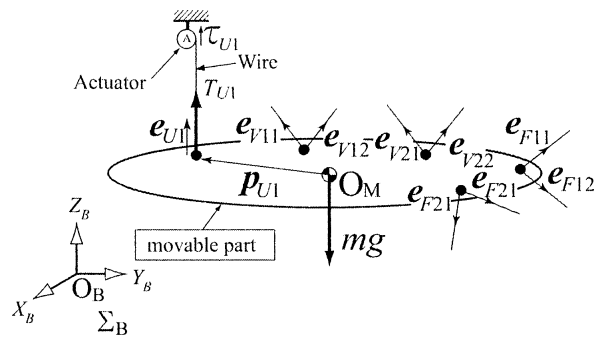

Fig. 4 Definitions of position vectors
であり, $\boldsymbol{E}_{U}, \boldsymbol{E}_{F}$ は単位行列, $\boldsymbol{W}_{M}$ は複ワイヤモジュールを 用いた場合におけるワイヤ行列である。

ここで，式（18）の両辺の項について説明する．まず，左辺の アクチュエータ速度の項の前にあるヤコビ行列 $\widetilde{\boldsymbol{J}}_{V}$ はアクチュ エー夕速度とワイヤ速度の間の関係を示しており，特に，速度 拘束型複ワイヤ駆動方式の成分 $\boldsymbol{J}_{V}$ は式（8）にあるようにア クチュエータ速度が 2 本のワイヤの速度を決定するということ を表している。また，右辺の可動部の速度の項の前にあるワイ ヤ行列 $\boldsymbol{W}_{M}$ はワイヤ張力と可動部で発生する力の間の関係を 示しているが, 力拘束型複ワイヤ駆動方式の成分 $\boldsymbol{W}_{F} \boldsymbol{J}_{F}^{\mathrm{T}}$ に関 しては，アクチュエータの駆動力と 2 本のワイヤの張力の間に 拘束関係があるため, ワイヤ行列 $\boldsymbol{W}_{F}$ だけでなく, 式 (14) に 示されているアクチュエータの駆動力が 2 本のワイヤの張力を 決定することを示すヤコビ行列 $\boldsymbol{J}_{F}^{T}$ を含んでいる.

ここで仮に，複ワイヤモジュールを使わずに単ワイヤモジュー ルのみで同様に構成した場合, 次式の運動学関係式が成り立つ.

$$
\begin{gathered}
\dot{\boldsymbol{q}}=\dot{\boldsymbol{l}} \\
\dot{\boldsymbol{l}}=\boldsymbol{W}_{U}^{\mathrm{T}} \boldsymbol{v}
\end{gathered}
$$

この式（22），(23）をまとめると，

$$
\dot{\boldsymbol{q}}=\boldsymbol{W}_{U}^{\mathrm{T}} \boldsymbol{v}
$$

となる。ここで得られた式 $(24)$ と複ワイヤ・メカニズムで構 成される運動学関係式，式（18）を比較すると，式（18）のよ うに複ワイヤモジュールを含む場合は，複ワイヤモジュールの 各型ごとのアクチュエータ速度とワイヤ速度との関係を示すヤ コビ行列が機構全体の運動学関係式にも現れるということが分 かる。

メカニズム全体のアクチュエータ速度と可動部の速度の関係 を表す，式（18）により，機構全体の運動学を表すことができ る.しかしながら, 式（18）のままでは可動部の速度 $\boldsymbol{v}$ を $\dot{\boldsymbol{q}}$ 関する陽な式に解き出すことはできない，その理由は，式 (6) の $\boldsymbol{J}_{V}$ が正方行列でないために, 式（18）を $\dot{\boldsymbol{q}}$ に関する陽な 式で表すことができないからである.

式（18）を $\dot{\boldsymbol{q}}$ に関する陽な式で表すことができない理由につ いて補足する。まず, 式（6）より，行列 $\boldsymbol{J}_{V}$ は, $K_{V}$ 行 $\alpha_{V}$ 列行列であり, 一つのアクチュエータが制御するワイヤの総数 は 2 本以上であるため, 速度拘束型複ワイヤモジュールのワイ ヤ総数 $K_{V}$ は，常にアクチュエータの数 $\alpha_{V}$ より大きくなる. そのため, 式（6）の $\boldsymbol{J}_{V}$ は正方行列ではないことが確認でき

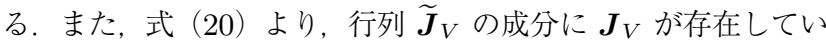
ることから $\widetilde{\boldsymbol{J}}_{V}$ が正方行列でないため，式（18）を $\dot{\boldsymbol{q}}$ に関す る陽な式で表すことはできない．

そこで，4 章では式（18）を満足する複ワイヤ駆動方式を用 いたパラレル・メカニズムの運動解析方法を提案する。この解 析方法は可動部で発生する速度の集合より可動部の能動拘束空 間と受動拘束空間および自由度を求める解析方法である。

\section{4 機構全体の静力学}

ここでは，静力学に関する定式化を行う，各ワイヤモジュー ルが可動部に対して並列結合で接続している場合，可動部の重 
心に加わる合力 $\boldsymbol{F}$ は各ワイヤモジュールでの合力の和となる ので, 次式が成り立つ.

$$
\boldsymbol{F}=\boldsymbol{F}_{U}+\boldsymbol{F}_{V}+\boldsymbol{F}_{F}
$$

ただし， $\boldsymbol{F}=\left[\begin{array}{lllll}f_{x} & f_{y} & f_{z} & n_{x} & n_{y} \\ n_{z}\end{array}\right]^{\mathrm{T}} \in \mathcal{R}^{6}$ である.

また，複ワイヤモジュールを含むメカニズムのワイヤ張力 $\boldsymbol{T}_{M}$ は次式で示される。

$$
\boldsymbol{T}_{M}=\left[\boldsymbol{T}_{U}^{\mathrm{T}} \boldsymbol{T}_{V}^{\mathrm{T}} \boldsymbol{\tau}_{F}^{\mathrm{T}}\right]^{\mathrm{T}}
$$

ただし， $\boldsymbol{T}_{M} \in \mathcal{R}^{K}$ であり，力拘束型複ワイヤモジュールの項 に関しては, ワイヤ行列にアクチュエータとワイヤの間の関係 が含まれているためアクチュエータ駆動力を行列の要素とした。

したがって，式 (21)，（25），(26）より各モジュールからな る全体の静力学関係式は, 次式のようになる.

$$
\boldsymbol{F}=\boldsymbol{W}_{M} \boldsymbol{T}_{M}
$$

また，重力を考慮した場合の全体の静力学関倸式を次式に示す。

$$
\boldsymbol{F}=\boldsymbol{W}_{M} \boldsymbol{T}_{M}+m g \boldsymbol{W}_{g}
$$

ただし， $\boldsymbol{W}_{g}\left(=\left[\begin{array}{llllll}0 & 0 & -1 & 0 & 0 & 0\end{array}\right]^{\mathrm{T}}\right)$ は重力方向ベクトルであ り, $f_{x}, f_{y}, f_{z}: X, Y, Z$ は軸方向に働く力, $n_{x}, n_{y}, n_{z}$ : $X, Y, Z$ は軸方向に働くモーメント, $K, m, g$ はそれぞれ ワイヤの総数, 可動部の質量, 重力加速度である.

ワイヤが弛まずに可動部の全方向を拘束するための条件は, Vector Closure の条件 [4] を適用することにより，次の二つの 条件になる。

条件 $1: \operatorname{rank}\left(\widetilde{\boldsymbol{W}}_{M}\right)=n$

条件 $2: \widetilde{\boldsymbol{W}}_{M} \widetilde{\boldsymbol{T}}_{M}=0, \quad \boldsymbol{T}_{M i}>0(1 \leq i \leq K)$

$$
\begin{aligned}
\widetilde{\boldsymbol{W}}_{M} & =\left[\boldsymbol{W}_{M} \boldsymbol{W}_{g}\right] \\
\widetilde{\boldsymbol{T}}_{M} & =\left[\boldsymbol{T}_{M}^{\mathrm{T}} m g\right]^{\mathrm{T}}
\end{aligned}
$$

である. また, $n$ は対象とする空間の次元であり, 式（28）の 場合は $n=6$ となる. 条件 1 は, 行列 $\widetilde{\boldsymbol{W}_{M}}$ の成分となるべ クトルのうち, $n$ 個のベクトルが線形独立であることを意味し, 条件 2 は，可動部で生じる合力が 0 となることを意味する。

\section{4. 運動自由度と運動方向の解析方法}

\section{1 速度の集合の導出}

本章では前章で定式化された一般的なワイヤメカニズムの運 動学より, 発生可能な可動部の速度の集合, および, 可動部の 動作可能な運動方向と自由度を求める方法を構築する.

まず，駆動方式ごとに可動部で発生できる速度の集合を求め る.この際，凸集合の考え方を元にアクチュエータ速度の集合 から可動部で発生できる速度の集合を求めていく。

まず，単ワイヤモジュールのアクチュエータ速度の集合 $\mathcal{Q}_{U}$ は以下のように求めることができる.

$$
\mathcal{Q}_{U}=\left\{\dot{\boldsymbol{q}}_{U} \mid \boldsymbol{A}_{Q U} \dot{\boldsymbol{q}}_{U} \leq \boldsymbol{b}_{Q U}\right\}
$$

ここで, 単ワイヤモジュールによって発生する可動部の速度 の集合 $\mathcal{V}_{U}$ は, 式（5）および, 式（31）より次式のように求め られる。

$$
\begin{aligned}
\mathcal{V}_{U} & =\left\{\boldsymbol{v}_{U} \mid \boldsymbol{A}_{Q U} \boldsymbol{W}_{U}^{\mathrm{T}} \boldsymbol{v}_{U} \leq \boldsymbol{b}_{Q U}\right\} \\
& =\left\{\boldsymbol{v}_{U} \mid \boldsymbol{A}_{V U} \boldsymbol{v}_{U} \leq \boldsymbol{b}_{V U}\right\}
\end{aligned}
$$

ただし $, \boldsymbol{A}_{V U}=\boldsymbol{A}_{Q U} \boldsymbol{W}_{U}^{\mathrm{T}}, \boldsymbol{b}_{V U}=\boldsymbol{b}_{Q U}$ である.

速度拘束型複ワイヤモジュールの場合, 式 (6) の $\boldsymbol{J}_{V}$ が正方 行列でないために, アクチュエー夕速度と可動部の速度の間の 関係式である式（11）を $\dot{\boldsymbol{q}}$ に関する陽な式で表すことができな い. そこで本論文では, ワイヤ速度の集合 $\mathcal{L}_{V}$ を幾何学的に求 め，その後式（10）を用いて可動部の速度の集合 $\mathcal{V}_{V}$ を求める. まず，ワイヤ速度の集合 $\mathcal{L}_{V}$ は以下のように表される。

$$
\mathcal{L}_{V}=\left\{\dot{\boldsymbol{l}}_{V} \mid \boldsymbol{A}_{L V} \dot{\boldsymbol{l}}_{V} \leq \boldsymbol{b}_{L V}\right\}
$$

ただし， $\boldsymbol{A}_{L V}, \boldsymbol{b}_{L V}$ は以下のようになる.

$$
\boldsymbol{A}_{L V}=\left[\begin{array}{ccccc}
-1 & 0 & 0 & \ldots & 0 \\
1 & 0 & 0 & \ldots & 0 \\
1 & -1 & 0 & \ldots & 0 \\
-1 & 1 & 0 & \ldots & 0 \\
1 & 0 & -1 & \ldots & 0 \\
-1 & 0 & 1 & \ldots & 0 \\
\vdots & \vdots & \vdots & \ddots & \vdots \\
1 & 0 & 0 & \cdots & -1 \\
-1 & 0 & 0 & \ldots & 1
\end{array}\right], \boldsymbol{b}_{L V}=\left[\begin{array}{c}
1 \\
1 \\
0 \\
0 \\
0 \\
0 \\
\vdots \\
0 \\
0
\end{array}\right]
$$

ここで，式（35）の構成方法について説明する。 まず， $\boldsymbol{A}_{L V}$ および $\boldsymbol{b}_{L V}$ の上からの 2 行が 1 本目のワイヤが発生可能な速 度の下限と上限に対応している。 また, 次の 2 行, さらにその 次の 2 行はそれぞれ 2 本目, 3 本目のワイヤの速度が 1 本目の ワイヤの速度と等しいということを意味している。 この方法は, 任意の速度拘束型複ワイヤモジュールを扱うことができるもの の, 方法の性格上, 式 (35) は一意に定まらない. しかし, 式 （35）が表現するワイヤ速度の集合は同一であるので，あとでの 解析の結果を左右するものではない. なお，この式（35）では $J_{V}$ で定まる速度の拡大を扱っていないが, この構成方法は速 度が拡大する場合にも適用できる。

速度拘束型複ワイヤモジュールによって発生する可動部の速 度の集合 $\mathcal{V}_{V}$ は，式（10）および，式（34）より次式のように 求められる.

$$
\begin{aligned}
\mathcal{V}_{V} & =\left\{\boldsymbol{v}_{V} \mid \boldsymbol{A}_{L V} \boldsymbol{W}_{V}^{\mathrm{T}} \boldsymbol{v}_{V} \leq \boldsymbol{b}_{L V}\right\} \\
& =\left\{\boldsymbol{v}_{V} \mid \boldsymbol{A}_{V V} \boldsymbol{v}_{V} \leq \boldsymbol{b}_{V V}\right\}
\end{aligned}
$$

ただし， $\boldsymbol{A}_{V V}=\boldsymbol{A}_{L V} \boldsymbol{W}_{V}^{\mathrm{T}}, \boldsymbol{b}_{V V}=\boldsymbol{b}_{L V}$ である.

また, 力拘束型複ワイヤモジュールのアクチュエータ速度の 集合 $\mathcal{Q}_{F}$ は以下のように表される.

$$
\mathcal{Q}_{F}=\left\{\dot{\boldsymbol{q}}_{F} \mid \boldsymbol{A}_{Q F} \dot{\boldsymbol{q}}_{F} \leq \boldsymbol{b}_{Q F}\right\}
$$


ここで, 力拘束型複ワイヤモジュールによって発生する可動部 の速度の集合 $\mathcal{V}_{F}$ は, 式（17）および, 式（38）より次式のよ うに求められる。

$$
\begin{aligned}
\mathcal{V}_{F} & =\left\{\boldsymbol{v}_{F} \mid \boldsymbol{A}_{Q F} \boldsymbol{J}_{F} \boldsymbol{W}_{F}^{\mathrm{T}} \boldsymbol{v}_{F} \leq \boldsymbol{b}_{Q F}\right\} \\
& =\left\{\boldsymbol{v}_{F} \mid \boldsymbol{A}_{V F} \boldsymbol{v}_{F} \leq \boldsymbol{b}_{V F}\right\}
\end{aligned}
$$

ただし， $\boldsymbol{A}_{V F}=\boldsymbol{A}_{Q F} \boldsymbol{J}_{F} \boldsymbol{W}_{F}^{\mathrm{T}}, \boldsymbol{b}_{V F}=\boldsymbol{b}_{Q F}$ である.

\section{2 運動自由度解析}

発生可能な可動部の速度の集合 $\mathcal{V}$ は, 前節で求めた各集合の 積集合を求めることで得られるので, 式 (33), （37），（40）を 用いて以下のような連立不等式の形で表現できる.

$$
\begin{aligned}
\mathcal{V} & =\left\{\boldsymbol{v} \mid \boldsymbol{A}_{V} \boldsymbol{v} \leq \boldsymbol{b}_{V}\right\} \\
& =\left\{\sum_{i=1}^{\beta} \lambda_{i} \boldsymbol{v}_{i} \mid \sum_{i=1}^{\beta} \lambda_{i}=1, \lambda_{i} \geq 0, i \in[1, \beta]\right\}
\end{aligned}
$$

となる. ただし, $\boldsymbol{v}_{i}(i \in[1, \beta])$ はV の頂点べクトル, $\beta$ は頂 点ベクトルの数であり,

$$
\begin{aligned}
\boldsymbol{A}_{V} & =\left[\begin{array}{lll}
\boldsymbol{A}_{V U}^{\mathrm{T}} & \boldsymbol{A}_{V V}^{\mathrm{T}} & \boldsymbol{A}_{V F}^{\mathrm{T}}
\end{array}\right]^{\mathrm{T}} \\
\boldsymbol{b}_{V} & =\left[\begin{array}{lll}
\boldsymbol{b}_{V U}^{\mathrm{T}} & \boldsymbol{b}_{V V}^{\mathrm{T}} & \boldsymbol{b}_{V F}^{\mathrm{T}}
\end{array}\right]^{\mathrm{T}}
\end{aligned}
$$

である.このように, face form の式である式 (41) から span form の式である式 (42) に変換することによって, 発生可能な 速度の集合を求めることができる.

次に式 $(42)$ の結果をもとに可動部の能動拘束空間 $\mathcal{S}_{A C}$ と 可動部の受動拘束空間 $\mathcal{S}_{P C}$ を求める.

式（42）中の頂点ベクトルから作る行列 $\boldsymbol{A}$ を

$$
\boldsymbol{A}=\left[\begin{array}{llll}
\boldsymbol{v}_{1} & \boldsymbol{v}_{2} & \cdots & \boldsymbol{v}_{\beta}
\end{array}\right]
$$

とすると, $\mathcal{S}_{A C}$ は発生可能な速度を含む部分集合になるので, $\mathcal{S}_{A C}$ は $\boldsymbol{A}$ の值域空間として, 次式で求められる.

$$
\mathcal{S}_{A C}=\mathcal{R}(\boldsymbol{A})
$$

ただし, $\mathcal{R}(\boldsymbol{A})$ は行列 $\boldsymbol{A}$ の值域空間である. 一方で, Vector Closure の条件を満たす機構の場合は, 外力が加わり受動的に 動作することはできないので, 可動部の非拘束空間 $\mathcal{S}_{U C}$ は空集 合となる. したがって, 可動部の受動拘束の空間 $\mathcal{S}_{P C}$ は $\mathcal{S}_{A C}$ の直交補空間になり, 次式で求めることができる.

$$
\mathcal{S}_{P C}=\mathcal{S}_{A C}{ }^{\perp}=\mathcal{N}\left(\boldsymbol{A}^{\mathrm{T}}\right)
$$

ただし, $\mathcal{N}\left(\boldsymbol{A}^{\mathrm{T}}\right)$ は行列 $\boldsymbol{A}^{\mathrm{T}}$ の零空間である.

また, 可動部の自由度数 $n$ は式 $(44)$ より, $\mathcal{S}_{A C}$ の次元数 として次式で表される.

$$
n=\operatorname{dim}\left(\mathcal{S}_{A C}\right)
$$

\section{5. 例 \\ 題}

\section{1 機構の定義}

本章では, 2 章の問題定義で示した Fig. 5 の機構を 4 章の手

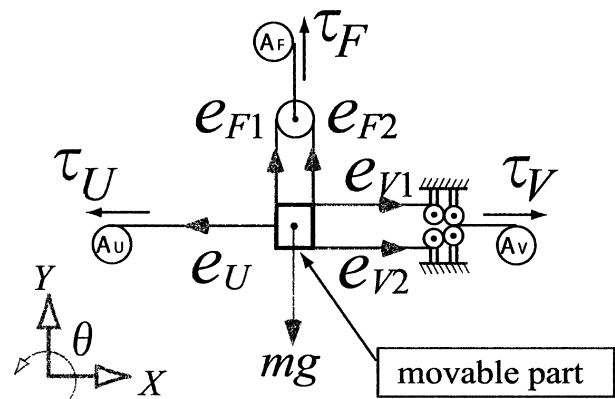

Fig. 5 An example of multi-wire driven parallel mechanism

法を用いて解析する。 この例題では, $x, y, \theta$ の 3 自由度を対象 としており，パラメータを以下のように設定する。また，それ ぞれの変数名については 3 章, 4 章を参照されたい.

$$
\begin{gathered}
\boldsymbol{e}_{U}=\left[\begin{array}{ll}
-1 & 0
\end{array}\right]^{\mathrm{T}}, \quad \boldsymbol{p}_{U}=\left[\begin{array}{ll}
-0.1 & 0
\end{array}\right]^{\mathrm{T}}, \\
\boldsymbol{e}_{V 1}=\left[\begin{array}{ll}
1 & 0
\end{array}\right]^{\mathrm{T}}, \quad \boldsymbol{p}_{V 1}=\left[\begin{array}{ll}
0.1 & 0.1
\end{array}\right]^{\mathrm{T}}, \\
\boldsymbol{e}_{V 2}=\left[\begin{array}{ll}
1 & 0
\end{array}\right]^{\mathrm{T}}, \quad \boldsymbol{p}_{V 2}=\left[\begin{array}{ll}
0.1 & -0.1
\end{array}\right]^{\mathrm{T}}, \\
\boldsymbol{e}_{F 1}=\left[\begin{array}{ll}
0 & 1
\end{array}\right]^{\mathrm{T}}, \quad \boldsymbol{p}_{F 1}=\left[\begin{array}{ll}
-0.1 & 0.1
\end{array}\right]^{\mathrm{T}}, \\
\boldsymbol{e}_{F 2}=\left[\begin{array}{ll}
0 & 1
\end{array}\right]^{\mathrm{T}}, \quad \boldsymbol{p}_{F 2}=\left[\begin{array}{ll}
0.1 & 0.1
\end{array}\right]^{\mathrm{T}}, \\
m g=1[\mathrm{~N}], \\
\dot{\boldsymbol{q}}_{U}^{\max }=\dot{\boldsymbol{q}}_{V}^{\max }=\dot{\boldsymbol{q}}_{F}^{\max }=1[\mathrm{~m} / \mathrm{s}], \\
\dot{\boldsymbol{q}}_{U}^{\min }=\dot{\boldsymbol{q}}_{V}^{\min }=\dot{\boldsymbol{q}}_{F}^{\min }=-1[\mathrm{~m} / \mathrm{s}]
\end{gathered}
$$

\section{2 運動方向と運動自由度の解析}

上記の設定より, 式 (3), (9), (15) 中のワイヤ行列および 式 (6)，（12）中のヤコビ行列, そして式 (21) 中のワイヤ行列 $\boldsymbol{W}_{F} \boldsymbol{J}_{F}^{\mathrm{T}}$ は以下のようになる.

$$
\begin{gathered}
\boldsymbol{W}_{U}=\left[\begin{array}{c}
-1 \\
0 \\
0
\end{array}\right], \boldsymbol{W}_{V}=\left[\begin{array}{cc}
1 & 1 \\
0 & 0 \\
-0.1 & 0.1
\end{array}\right], \quad \boldsymbol{W}_{F}=\left[\begin{array}{cc}
0 & 0 \\
1 & 1 \\
-0.1 & 0.1
\end{array}\right], \\
\boldsymbol{J}_{V}=\left[\begin{array}{l}
1 \\
1
\end{array}\right], \quad \boldsymbol{J}_{F}^{\mathrm{T}}=\left[\begin{array}{c}
\frac{1}{2} \\
\frac{1}{2}
\end{array}\right], \quad \boldsymbol{W}_{F} \boldsymbol{J}_{F}^{\mathrm{T}}=\left[\begin{array}{l}
0 \\
1 \\
0
\end{array}\right]
\end{gathered}
$$

また, 式（27）中のワイヤ行列および重力項, 式 (29) 中の ワイヤ行列はそれぞれ以下のようになる.

$$
\begin{gathered}
\boldsymbol{W}_{M}=\left[\begin{array}{cccc}
-1 & 1 & 1 & 0 \\
0 & 0 & 0 & 1 \\
0 & -0.1 & 0.1 & 0
\end{array}\right], \quad \boldsymbol{W}_{g}=\left[\begin{array}{c}
0 \\
-1 \\
0
\end{array}\right] \\
\widetilde{\boldsymbol{W}}_{M}=\left[\begin{array}{ccccc}
-1 & 1 & 1 & 0 & 0 \\
0 & 0 & 0 & 1 & -1 \\
0 & -0.1 & 0.1 & 0 & 0
\end{array}\right]
\end{gathered}
$$

ここで, Fig. 5 の機構が Vector Closure の条件を満たすこ とを示す. Fig. 5 の機構は平面運動を対象としているので, こ の例題で扱う次元数は 3 である。 また, 式 (47) の階数は, $\operatorname{rank}\left(\widetilde{\boldsymbol{W}}_{M}\right)=3$ なので, Vector Closure の条件 1 を満足する. 
さらに，例えば $\widetilde{\boldsymbol{T}}_{M}=\left[\begin{array}{lllll}1 & 0.5 & 0.5 & 1 & 1\end{array}\right]^{\mathrm{T}}$ のとき $\widetilde{\boldsymbol{W}}_{M} \widetilde{\boldsymbol{T}}_{M}=0$ となり, すべての張力が正となる Vector Closure の条件 2 を 満足する. したがって, Fig. 5 の機構は Vector Closure の条件 を満足する。また, このワイヤ・メカニズムの運動学関倸式, 式 （18）は以下のようになる.

$$
\left[\begin{array}{lll}
1 & 0 & 0 \\
0 & 1 & 0 \\
0 & 1 & 0 \\
0 & 0 & 1
\end{array}\right]\left[\begin{array}{l}
\boldsymbol{q}_{U} \\
\boldsymbol{q}_{V} \\
\boldsymbol{q}_{F}
\end{array}\right]=\left[\begin{array}{ccc}
-1 & 0 & 0 \\
1 & 0 & -0.1 \\
1 & 0 & 0.1 \\
0 & 1 & 0
\end{array}\right]\left[\begin{array}{l}
\boldsymbol{v}_{\boldsymbol{x}} \\
\boldsymbol{v}_{\boldsymbol{y}} \\
\boldsymbol{v}_{\boldsymbol{\theta}}
\end{array}\right]
$$

式（48）両辺の $4 \times 3$ 行列の成分はワイヤ速度の大きさを比較 して㧍り, 左辺 1 列目は単ワイヤモジュールによって発生する 速度の成分， 2 列目， 3 列目はそれぞれ速度拘束型複ワイヤモ ジュール, 力拘束型複ワイヤモジュールによって発生する速度 の成分である。また，右辺は 1 列目， 2 列目， 3 列目がそれぞ れ可動部の $X, Y, \theta$ 方向に発生する速度の成分を表している.

次に, 発生可能な可動部の速度, 能動拘束空間, 受動拘束空間 を求める. まず, 5.1 節の定義により, 式 (31)，（34），(38）中 の $\boldsymbol{A}_{Q U}, \boldsymbol{b}_{Q U}, \boldsymbol{A}_{L V}, \boldsymbol{b}_{L V}, \boldsymbol{A}_{Q F}, \boldsymbol{b}_{Q F}$ は以下のようになる.

$$
\begin{gathered}
\boldsymbol{A}_{Q U}=\boldsymbol{A}_{Q F}=\left[\begin{array}{r}
-1 \\
1
\end{array}\right], \quad \boldsymbol{b}_{Q U}=\boldsymbol{b}_{Q F}=\left[\begin{array}{l}
1 \\
1
\end{array}\right] \\
\boldsymbol{A}_{L V}=\left[\begin{array}{rr}
-1 & 0 \\
1 & 0 \\
1 & -1 \\
-1 & 1
\end{array}\right], \quad \boldsymbol{b}_{L V}=\left[\begin{array}{l}
1 \\
1 \\
0 \\
0
\end{array}\right]
\end{gathered}
$$

上記のパラメータより, 式 (33), (37), (40) 中の $\boldsymbol{A}_{V U}, \boldsymbol{b}_{V U}$, $\boldsymbol{A}_{V V}, \boldsymbol{b}_{V V}, \boldsymbol{A}_{V F}, \boldsymbol{b}_{V F}$ および式 (41) 中の $\boldsymbol{A}_{V}, \boldsymbol{b}_{V}$ は

$$
\begin{gathered}
\boldsymbol{A}_{V U}=\left[\begin{array}{rrr}
1 & 0 & 0 \\
-1 & 0 & 0
\end{array}\right], \quad \boldsymbol{b}_{V U}=\left[\begin{array}{l}
1 \\
1
\end{array}\right] \\
\boldsymbol{A}_{V V}=\left[\begin{array}{rrr}
-1 & 0 & 0.1 \\
1 & 0 & -0.1 \\
0 & 0 & -0.2 \\
0 & 0 & 0.2
\end{array}\right], \quad \boldsymbol{b}_{V V}=\left[\begin{array}{l}
1 \\
1 \\
0 \\
0
\end{array}\right] \\
\boldsymbol{A}_{V F}=\left[\begin{array}{ccc}
0 & -1 & 0 \\
0 & 1 & 0
\end{array}\right], \quad \boldsymbol{b}_{V F}=\left[\begin{array}{l}
1 \\
1
\end{array}\right] \\
\boldsymbol{A}_{V}=\left[\begin{array}{ccc}
1 & 0 & 0 \\
-1 & 0 & 0 \\
-1 & 0 & 0.1 \\
1 & 0 & -0.1 \\
0 & 0 & -0.2 \\
0 & 0 & 0.2 \\
0 & -1 & 0 \\
0 & 1 & 0
\end{array}\right], \quad \boldsymbol{b}_{V}=\left[\begin{array}{l}
1 \\
1 \\
1 \\
1 \\
0 \\
0 \\
1 \\
1
\end{array}\right]
\end{gathered}
$$

となる. 式 (42) より発生可能な可動部の速度べクトルの集合

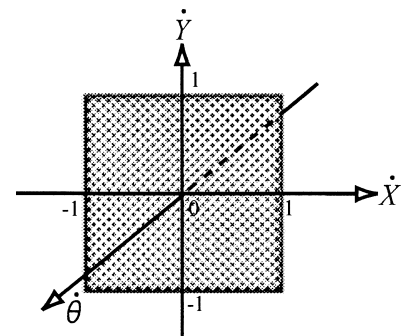

Fig. 6 A set of possible velocities of movable part

の頂点ベクトルは

$$
\boldsymbol{v}_{i}=\left[\begin{array}{r}
-1 \\
-1 \\
0
\end{array}\right],\left[\begin{array}{r}
1 \\
-1 \\
0
\end{array}\right],\left[\begin{array}{l}
1 \\
1 \\
0
\end{array}\right],\left[\begin{array}{r}
-1 \\
1 \\
0
\end{array}\right]
$$

となる. なお, face form から span form への変換は, 比留川 の方法 [11] を使用した. 発生可能な可動部の速度べクトルの集 合の図を Fig. 6 に示す. Fig. 6 は, 発生可能な可動部の速度べ クトルの集合が $\dot{\theta}=0$ の平面に含まれる集合になっており, 可 動部の姿勢を変化させる速度 $\dot{\theta}$ は発生しないことを表している.

また, 式（43）より, 頂点べクトルから作る行列 $\boldsymbol{A}$ は以下 のようになる.

$$
\boldsymbol{A}=\left[\begin{array}{cccc}
-1 & 1 & 1 & -1 \\
-1 & -1 & 1 & 1 \\
0 & 0 & 0 & 0
\end{array}\right]
$$

よって, 式 (44), (45), (46) より, 可動部全体の能動拘束と 受動拘束の空間および可動部の自由度数は以下のようになる。

$$
\begin{gathered}
\mathcal{S}_{A C}=\mathcal{R}\left(\left[\begin{array}{ll}
1 & 0 \\
0 & 1 \\
0 & 0
\end{array}\right]\right), \quad \mathcal{S}_{P C}=\mathcal{R}\left(\left[\begin{array}{l}
0 \\
0 \\
1
\end{array}\right]\right) \\
\operatorname{dim}\left(\mathcal{S}_{A C}\right)=2
\end{gathered}
$$

なお， $\mathcal{S}_{U C}=\{\phi\}$ である. 式 $(55)$ の $\mathcal{S}_{A C}$ の結果は, Fig. 6 に図示されたものと符合するものであることが分かる.

以上の結果より, 本例題で求められた結果は幾何学的な考察 と一致するので, 本章で構築した運動方向と運動自由度の解析 方法は妥当である.

\section{6. 終わりに}

本論文で得られた結論は，以下の通りである。

1）一つのアクチュエータが 1 本のワイヤ先端の位置や力を 制御する機構, および一つのアクチュエータが複数のワ イヤ先端の位置や力を制御する機構の定義と特徵を明ら かにした，また，それらの組み合わせで構成されるワイ ヤ駆動型パラレル・メカニズムの運動自由度解析のため の定式化を行った。この定式化ではアクチュエータ速度 と可動部の速度の間の運動学を明らかにした。

2）凸解析の手法を利用して，複ワイヤ駆動方式を用いたパ ラレルメカニズムの可動部の運動方向と運動自由度を求 
永井清吉田

める運動自由度解析方法を提案し, 例題を用いてその妥 当性を示した．本論文で得られた運動自由度解析方法に より, 複ワイヤ駆動方式に基づくパラレル・メカニズム を用いて, 可動部が特定の方向に動作できない受動拘束 を生じさせることや，アクチュエータの駆動力を分散さ せて可動部に伝えることが可能となる。

本論文で述べた定義と名称を用いると, 自立支援用パワーア シスト装置 [8] も複ワイヤ・メカニズムと呼ぶべきものとなる. そして本手法を適用することにより，設計時に，ワイヤ構造の 妥当性を検証するための運動自由度解析が可能となる。

\section{参 考 文 献}

[ 1 ] 川村, 崔, 田中, 木野: “パラレルワイヤ駆動方式を用いた超高速ロボッ トFALCON の開発”, 日本ロボット学会誌, vol.15, no.1, pp.82-89, 1997.

[2] 本間, 新井: “パラレルメカニズムを用いた上肢動作補助機構”, 日本 ロボット学会誌, vol.15, no.1, pp.90-96, 1997.

[3] 大隅, 沈, 新井： “ワイヤ懸垂系における操り指標”, 日本ロボット学 会誌, vol.12, no.7, pp.1049-1055, 1994.

[4] S. Kawamura and K. Ito: "A New Type of Master Robot for Teleoperation Using A Radial Wire Drive System," Proceedings of 2002 IEEE/RSJ International Conference on Intelligent Robots and Systems, pp.55-60, 1993.

[5]吉川：“把持と操りの基礎理論 1. 受動拘束と能動拘束”, 日本口 ボット学会誌, vol.13, no.7, pp.950-957, 1995.

[ 6 ] 鄭, 友近, 吉川 : “複数のロボット機構による協調的操り時の動的可 操作性”, 日本ロボット学会誌, vol.11, no.6, pp.892-900, 1993.

[7] 張, 中村, 吉本: “不完全な接触をもつ把持の力学的多面凸解析”, 日 本ロボット学会誌, vol.14, no.1, pp.105-113, 1996.

[8] K. Nagai, H. Hanafusa, Y. Takahashi, H. Bunki, I. Nakanishi, T. Yoshinaga and T. Ehara: "Development of a Power Assistive Device for Self-Supported Transfer Motion," Proceedings of 2002 IEEE/RSJ International Conference on Intelligent Robots and Systems, pp.1433-1438, 2002.

[ 9] V. フバータル：線形計画法 (下). 啓学出版, 1988.

[10] 比留川, 松井, 高瀬: “多面体間の接触による拘束条件を幾何モデル から導出する一般的なアルゴリズム”, 日本ロボット学会誌, vol.9, no.4, pp.415-426, 1991.

[11] 比留川, 松井, 高瀬： “多面体間の接触による拘束条件の高速解法 とその離脱動作計画への応用”, 日本ロボット学会誌, vol.9, no.7, pp.841-848, 1991.
創吉森大 悟

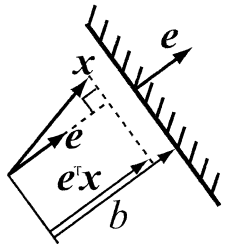

(a) face form

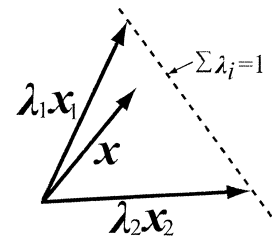

(b) span form
Fig. 7 Expression form of polyhedral convex set

\section{付録 A. 多面凸集合の表現形式}

多面凸集合 $\mathcal{C}$ は以下のように表現することができる.

$$
\begin{aligned}
\mathcal{C} & =\{\boldsymbol{v} \mid \boldsymbol{A} \boldsymbol{x} \leq \boldsymbol{b}\} \\
& =\left\{\sum_{i=1}^{r} \lambda_{i} \boldsymbol{x}_{i} \mid \sum_{i=1}^{r} \lambda_{i}=1, \lambda_{i} \geq 0\right\}
\end{aligned}
$$

式 (A.1), 式 (A.2) はそれぞれ, 多面凸集合 $\mathcal{C}$ の外部的な表 現 (face form), 内部的な表現 (span form) といい, それぞれ の概念図を Fig. 7 に示す. face form と span form はともに, 同一の境界面に関して, 境界面の位置と姿勢, および集合がど ちら側に存在するかということを異なる表現で表している：二 つの表現間の変換は幅優先探索法で行うことができる [9]. また, 拘束条件を幾何モデルから導出するアルゴリズム [10] や, 特異 值分解を適用した高速解法 [11] が開発されている。

\section{付録 B．アクチュエータ速度の集合の導出}

アクチュエータ速度の集合 $\mathcal{Q}$ は, アクチュエータが発生可能 な速度の範囲より求めることができる。例えば, Fig. 5 の機構 において, 単ワイヤ駆動方式のアクチュエータが発生可能な速 度の範囲は， $-1 \leq \dot{\boldsymbol{q}}_{U} \leq 1$ という式で表される。また，この 式は以下の式と等価である。

$$
\left[\begin{array}{r}
-1 \\
1
\end{array}\right] \dot{\boldsymbol{q}}_{U} \leq\left[\begin{array}{l}
1 \\
1
\end{array}\right]
$$

ここで, $\boldsymbol{A}_{Q U}=[-1,1]^{\mathrm{T}}, \quad \boldsymbol{b}_{Q U}=[1,1]^{\mathrm{T}}$ とおくことで, 式 （31）の形でアクチュエー夕速度の集合を表すことができる.

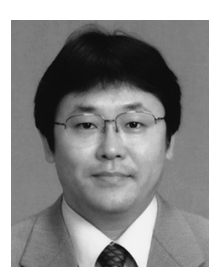

永井 清 (Kiyoshi Nagai)

1987 年京都大学大学院工学研究科中途退学. 同年, 立命館大学理工学部助手 (情報工学科). 1995 年同 学部助教授 (同学科). 1996 年同学部助教授 (ロボ ティクス学科), 2007 年同学部教授 (同学科), 現 在に至る。この間, 1995 年から 1996 年米国ス夕 ンフォード大学客員研究員, 2004 年から 2005 年 英国レディング大学客員研究員. 博士 (工学).ロボット工学の研究 に従事. 日本機械学会, 計測自動制御学会, IEEE などの会員.

(日本ロボット学会正会員)

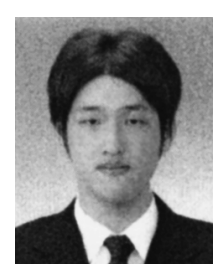

吉田 創 (Hajime Yoshida)

2010 年 3 月立命館大学理工学部ロボティクス学科 卒業. 同年同大学大学院理工学研究科博士課程前期 課程創造理工学専攻 (機械システムコース) 入学, 現在に至る.

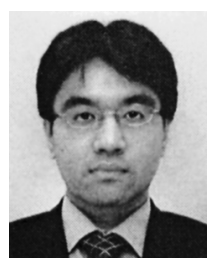

吉森大悟 (Daigo Yoshimori)

2009 年 3 月立命館大学院理工学研究科博士前期課 程前期創造理工学専攻 (機械システムコース) 修了. 同年アイシン精機株式会社入社. 現在に至る. 